\title{
O que é um banco? Uma análise das teorias de bancos em Wicksell e Keynes
}

\author{
What is a bank? An Analysis of bank theories in Wicksell and Keynes
}

\author{
Daniel de Santana Vasconcelos ${ }^{\mathrm{I}}$
}

\begin{abstract}
RESUMO
O presente trabalho analisa as teorias originais de bancos nos escritos de Knut Wicksell e John M. Keynes. Esses dois autores, argumenta-se, delimitaram os contornos das teorias de fundos emprestáveis, no mainstream econômico (Wicksell), e as teorias heterodoxas com foco na preferência pela liquidez dos bancos (Keynes). O trabalho detalha como a teoria wickselliana fica limitada pela tentativa de conciliar bancos e crédito numa corn economy, limitada pela TQM, e como a obra de Keynes, no Treatise on Money, não obstante ainda preso à TQM, conseguiu avançar para um entendimento sistemático dos bancos e da necessidade de regulação bancária nas economias monetárias. Palavras-Chave: Bancos; Fundos emprestáveis; Preferência pela liquidez
\end{abstract}

\begin{abstract}
This paper analyzes the original banking theories in the writings of Knut Wicksell and John M. Keynes. These two authors, it is argued, delimited the boundaries of loanable funds theory, in the economic mainstream (Wicksell), and heterodox theories focusing on bank's liquidity preference (Keynes). The paper details how wicksellian theory is limited by the attempt to reconcile banks and credit into a corn economy, limited by QT, and how the work of Keynes in his Treatise on Money, despite still attached to the QT, advanced towards a systematic understanding of banks and the need for bank regulation in monetary economies.
\end{abstract}

Keywords: Banks; Loanable funds; Liquidity preference 


\section{Introdução}

Uma análise geral das teorias ortodoxas sobre bancos permite concluir que, rigorosamente falando, à exceção de maior sofisticação matemática ou de argumentos que levam em conta fenômenos de pesquisa mais recente em economia (em particular, custos de transação e desenho de contratos), nenhuma dessas teorias é realmente uma inovação teórica capaz de uma ruptura fundamental numa escola de pensamento. ${ }^{1}$ As teorias bancárias mais inovadoras, e que realmente foram capazes de engendrar profundas mudanças no modo de se compreender o objeto banco estão situadas num período anterior da análise econômica. É hipótese de fundo desse trabalho que parte importante das grandes áreas cinzentas com as quais se lida hoje em dia na área de regulação bancária e financeira se deve ao fato de que, à medida que os tratamentos teóricos foram ficando matematicamente mais sofisticados, foram perdendo em perspectiva. A visão dos analistas, ao estreitar-se demais num dado problema a respeito do objeto, deixou de enxergar o objeto por completo, em suas interações com o meio econômico, social, e mais ainda, histórico e institucional que o circunda.

Resultou daí um empobrecimento da análise teórica sobre bancos no âmbito da teoria econômica. Na perspectiva defendida no presente trabalho é necessário encontrar as fontes teóricas mais fundamentais em que bancos foram analiticamente tratados, que foram capazes de engendrar desenvolvimentos teóricos subsequentes. Sob esse critério, constata-se que as duas principais correntes teóricas que debatem o objeto banco, a corrente mainstream, de recorte ortodoxo, e as propostas heterodoxas, têm em dois autores de teorias bancárias suas fontes mais profundas e originais. Esses dois autores são Knut Wicksell e John Maynard Keynes. O segundo é amplamente reconhecido por sua contribuição teórica fundamental nas diversas escolas heterodoxas, e em particular na corrente pós-keynesiana. Wicksell não goza do mesmo reconhecimento, mesmo entre os praticantes da ortodoxia. No que diz respeito ao objeto do presente trabalho, em ambos o banco não é uma firma neoclássica típica - uma função de produção maximizadora de lucros, pura e simplesmente - tendo uma presença mais bem definida dentro de um escopo maior, como instituição de um sistema econômico mais complexo e mais aderente à realidade.

O objetivo do presente trabalho é realizar uma análise do tratamento dado aos bancos na teoria desses dois economistas. Ambos estiveram envolvidos com os debates sobre as condições de funcionamento das modernas economias monetárias, ainda dentro da tradição da Teoria Quantitativa da Moeda (TQM), embora Keynes mais tarde tenha abertamente rompido com essa escola. A forma como cada um deles desenvolveu sua abordagem teórica, contudo, desembocou em diferentes visões da função dos bancos no sistema econômico. Como se verá na seção 2 do presente trabalho, Wicksell enfatizou o papel intermediário e passivo dos bancos como alocadores de poupança entre agentes com diferentes graus de disponibilidades financeiras - análise que, enfim, sobreviveu como mola mestra da análise mainstream. Sua teoria circunscreveu os limites das chamadas teorias de fundos emprestáveis (TFE). Keynes, percorrendo outro caminho, deu aos bancos um papel de protagonistas na economia, colocando-os no mesmo patamar que as empresas de uma economia empresarial moderna, ou seja, como agentes ativos com objetivos, estratégias e expectativas - como será abordado na seção 3. Além disso, a teoria keynesiana permitiu a primeira aproximação de como funciona um sistema financeiro regulado que não se limita a um mundo de moeda mercadoria (commodity-money). Concluindo, veremos que esta constitui-se na principal limitação de todos os modelos que, como os de Wicksell, ainda trabalham nos estritos limites da TQM.

\section{Os Bancos em Wicksell}

Wicksell ofereceu à teoria econômica uma abordagem original e inovadora no tratamento da instituição bancária. Sua perspectiva foi definidora de toda uma escola de pensamento a respeito das teorias de poupança, as chamadas teorias de fundos emprestáveis (TFE). Nesse sentido, entretanto, pode-se avaliar suas contribuições como uma continuidade da visão clássica de uma economia do tipo corn economy. ${ }^{2}$ Nessa abordagem, o objetivo da análise econômica seria mostrar comomesmo uma economia de mercado seria apenas uma expressão, em essência, dos mesmos mecanismos de uma economia extremamente simples, sem a existência - ou a interferência - da moeda.

Numa corn economy, a poupança é tratada como constituindo uma parte do produto que não é consumida agora, para ser consumida em momento posterior. O produto total é algo dado, um volume total, uma quantidade física determinada pela capacidade de oferta da economia. A poupança retira uma parte desse produto total de seu consumo presente para consumo futuro. Enquanto o consumo é, nessa perspectiva, uma forma de destruição de produto, a poupança é a retenção de uma parte do produto para não-uso presente - a poupança é acumulação, regrada por um comportamento parcimonioso em relação ao consumo. Seria uma forma de demanda para outro uso, portanto.

Nessa economia mesmo a introdução de moeda não alteraria em nada os seus mecanismos de funcionamento, já que a

${ }^{1}$ As teorias ortodoxas de maior impacto na literatura podem ser encontradas em Baltensperger (1980); Diamond e Dybvig (1983); Fama (1980). Para uma síntese das teorias ortodoxas, vide Freixas e Rochet (2008).

${ }^{2} \mathrm{~A}$ terminologia deriva do conhecido modelo analítico de Ricardo (apresentado no Essay on the influence of a low price of corn on the profits of stock, de 1815), sobre a economia do trigo (ou cereal), na qual a economia produzia um único produto, que era também a medida universal de salários, lucros e o próprio insumo cuja acumulação implicava em maior produto no futuro (investimento). 
moeda é introduzida nas transações apenas como um "representante", denominado em nome de outra mercadoria, que pode ser, como no modelo de Ricardo, uma commodity qualquer. A moeda é apenas um nome para algo que denomina quantidades do produto, um numerário. A poupança, portanto, é "não consumo" de produto, mesmo que seja denominada em moeda. Esse contexto é fundamental para a compreensão do modelo analítico do banco wickselliano.

\section{1 - A economia monetária de Wicksell: poupança e papel dos bancos}

Wicksell surge na seara do debate econômico num contexto em que a discussão clássica sobre a acumulação e crescimento fora substituída pela busca da compreensão das propriedades e mecanismos de funcionamento da mão invisível, de Smith. Derivando sua teoria do capital de Böhn-Bawerk, Wicksell esteve mais fortemente ligado ao que Ohlin denominou mais tarde como a escola de Estocolmo, cujas características definidoras eram a ênfase analítica não matematizada, a consideração a respeito da existência da incerteza fundamental em economia (próxima, mas não igual à incerteza keynesiana), e tendo no capital o seu conceito chave. ${ }^{3}$

Na sua abordagem, a moeda passa a ser objeto de consideração do próprio conceito de capital, de onde derivam duas considerações importantes: como tratar a moeda que, de um lado, serviria somente como veículo das trocas, mas de outro, podia ser acumulada para constituir capital, e o papel dos bancos numa economia monetária. Para os austríacos, de uma forma sintética, o problema para o conceito de capital é dado lançando mão da análise temporal: acumular capital implica em processos mais lentos de obtenção do produto final. No processo de acumulação, existem processos intermediários que são mais extensos no tempo do que a produção de bens finais. Todavia, a produtividade final advinda da acumulação é muito maior (mais que proporcional) em relação ao uso de insumos. ${ }^{4}$

Wicksell herda essa noção da essencialidade do tempo no conceito de capital e de acumulação. Porém, sendo fiel à abordagem de acumulação, vai trazer para o debate a questão da moeda, que havia sido marginalizada em Smith. A essência do capital é tempo, mas o processo de acumulação é fundamentado na poupança, e esta se dá na forma de poupança monetária. A expansão produtiva está em algum grau interligada aos determinantes da estrutura monetária da economia. O capital real possui uma contraparte denominada em moeda, ou um capital monetário, digno de investigação. Assim, no primeiro volume do seu Lectures on Political Economy, Wicksell trata de uma economia real, sem moeda, de equilíbrio do tipo walrasiano, ao passo que no segundo volume ele introduz e tenta analisar em que condições a moeda, mesmo numa economia moderna na qual todas as transações relevantes são nela denominadas, não altera as condições fundamentais de determinação do equilíbrio. ${ }^{6}$

A introdução da moeda numa economia cuja essência ainda é de uma corn economy, no volume II das Lectures, gera para Wicksell uma série de problemas que ele busca tratar ainda sob o guarda-chuva da TQM. Estes problemas dizem respeito a diferenciar poupança de entesouramento (pois os dois fenômenos teriam efeitos diferentes sobre a velocidade de circulação da moeda ${ }^{7}$ ); qual seria o efeito sobre os preços da ação de despoupar; como explicar a origem da poupança (na sua forma monetária), e como explicar o equilíbrio resultante. ${ }^{8}$

Do ponto de vista da TQM, a dificuldade reside no fato de como diferenciar entesouramento de poupança. Enquanto o primeiro, se argumentava, retira moeda de circulação, reduzindo preços (ceteris paribus), a defesa de natureza "moral” das virtudes da segunda (a ideia da parcimônia tendo sido sempre um ponto nobre para a análise clássica) forçava o analista a buscar uma explicação em que a poupança não tivesse efeito deletério sobre os preços nem sobre o produto. ${ }^{9}$ Assim, a poupança é o veículo de acumulação de capital em Wicksell:

[...] capital is not (...) physically limited. It can be increased at any moment by saving; it can be reduced by unproductive consumption. Neither is the supply of capital renewed in the same way as the supply of labor, by the work of nature (...). A rational theory of saving is thus necessary before we can clearly understand the conditions of a stationary society, with

${ }^{3}$ Num cenário de debates dominado pela figura de Marshall, com a análise de equilíbrio parcial, e pela crescente influência de modelos matematizados dos marginalistas, Wicksell, grandemente ofuscado também por escrever em outro idioma, mantém-se fiel à tradição smithiana, embora partindo de uma abordagem diferente.

${ }^{4}$ Uma máquina, por exemplo, demora um tempo maior para ser produzida, mas uma vez acabada e colocada em uso, vai produzir mais e por um longo período de tempo. A máquina, portanto, prolonga no tempo (intertemporalmente) o processo produtivo (amplia o roundaboutness, de Böhn-Bawerk).

${ }^{5}$ Daqui por diante, sempre citado como Lectures, seguido do Volume (I ou II). Vide Wicksell, 1934 (I); 1935 (II).

${ }^{6}$ Wicksell reconhece, no entanto, que há limitações na análise econômica que se prenda a "leis econômicas" vigentes numa economia de trocas puras quando elas são aplicadas sem qualificação a uma economia monetizada: "Economists frequently go too far when they assume that the economic laws which they have deduced on barter assumptions may be applied without qualification to actual conditions, in which money actually effects practically all exchanges and investments or transfers of capital." (Lectures, II, pg. 6)

${ }^{7} \mathrm{Na}$ verdade, considerando a equação quantitativa (MV=PY) poupar não tem, por si mesmo, nenhum efeito identificável sobre $\mathrm{V}$, a velocidade de circulação da moeda, porque se poupar significar comprar mercadorias para consumo futuro, o volume de transações não se altera, nem, portanto, a velocidade de circulação da moeda; já entesourar necessariamente diminui V.

${ }^{8} \mathrm{O}$ nó górdio da análise wickselliana, nesse ponto, é entender uma dificuldade de natureza prática: conceitualmente, segundo a análise econômica na qual ele fora formado, a ideia norteadora sempre foi a de que o crescimento do capital é real. Assim como numa corn economy, o produto (físico) acumulado é que gera mais produto, produzido num segundo momento. Mas, para que ocorra a acumulação, o produto, de fato, não é acumulado fisicamente: a poupança que se verifica existir, de fato, é monetária. Assim, como explicar a expansão da poupança monetária sem romper a identidade fundamental da TQM?

9"Capitals are increased by parsimony, and diminishes by prodigality and misconduct" escreveu Smith no capítulo 3, Livro II, da Wealth of Nations. E mais à frente, arremata: "Parsimony, and not industry, is the immediate cause of the increase of capital. Industry, indeed, provides the subject which parsimony accumulates. But whatever industry might acquire, if parsimony did not save and store up, the capital would never be the greater." 
a constant supply of capital; and still more, of course, before we can understand and foresee the gradual changes in the amount of social capital. (Lectures, I, p. 207)

Wicksell é, em certo sentido, pioneiro na tentativa de tratar adequadamente na teoria econômica o fato de que a poupança é monetária e cresce monetariamente, pela expansão de ativos denominados em moeda, inclusive depósitos bancários. Além disso, em termos institucionais, o locus da expansão das poupanças se dá fundamentalmente nos bancos. Mais importante ainda, percebe-se empiricamente que nos bancos a moeda não é somente "guardada"; em algum grau, ela é até mesmo gerada neles. Não obstante esses "fatos estilizados", poupança monetária e bancos não são contemplados senão marginalmente na análise clássica de economia. ${ }^{10}$

A herança clássica da TQM carrega essa limitação: a criação de moedas pelos bancos é um problema com a qual a TQM não consegue lidar. Em Wicksell esses fenômenos serão objeto de uma tentativa de integração à teoria quantitativa. A poupança monetária revela o papel importante que os bancos exercem no sistema econômico, e em sua abordagem Wicksell eleva o banco ao status de um dos elementos basilares da formatação do mecanismo de funcionamento normal de uma economia monetária.

A pergunta que deve ser respondida, então, é: “por que os indivíduos poupam”? Para Wicksell, poupar é um problema derivado da decisão de consumir, e essa decisão de consumir se dá no tempo: toda escolha de consumo é um escolha entre consumir hoje ou consumir no futuro. O consumo é a meta do indivíduo, sempre, mas o tempo de sua realização pode ser variado - preferências pessoais, maior ou menor parcimônia, são decisões que afetam a escolha temporal em torno do consumo. As pessoas são, portanto, capazes de decidir entre consumir no presente ou no futuro. A poupança é, portanto, o instrumento de consumo futuro à disposição dos indivíduos.

Em termos teóricos Wicksell está introduzindo uma função poupança que explica a decisão de poupar: os indivíduos maximizam intertemporalmente a satisfação de consumir, derivada da poupança. A poupança, realizada em forma de poupança de moeda, simplesmente transfere poder de compra do presente para o futuro. ${ }^{11} \mathrm{O}$ indivíduo racional poupa até que a utilidade marginal de poupar iguale a utilidade marginal de consumir no presente, dada a psicologia dos indivíduos, na qual consumo presente gera mais satisfação que o futuro. O indivíduo escolhe consumir no futuro quando é recompensado por sua parcimônia, por meio do pagamento de juros positivos sobre a poupança realizada.

Nesse modelo de visão do sistema econômico, Wicksell introduz o banco como agente cuja função é atuar como intermediário financeiro: alocar recursos entre os diferentes agentes, tomando recursos de alguns indivíduos (as poupanças depositadas são "empréstimos" aos bancos) e repassando, também via empréstimos, a outros. A poupança constitui uma forma de transferência temporária de direitos sobre a demanda, por meio da qual o poupador disponibiliza seus recursos (depositados em bancos para receber uma remuneração na forma de juros) para outros agentes, que tomam empréstimos junto aos bancos para financiar suas atividades. O banco wickselliano (nesse, e somente nesse sentido) empresta exatamente o mesmo volume que obteve emprestado. A moeda poupada é mantida em circulação por meio desse expediente de alocação entre agentes com diferentes estruturas superavitárias/deficitárias. Em assim agindo, a instituição econômica banco, assim como a moeda, não altera em nada a economia, porque apenas faz o dinheiro girar entre diferentes carteiras.

A demanda por moeda existe porque ocorre uma assincronia entre recebimentos de moeda e pagamentos realizados com ela. Para Wicksell, sempre existe, a qualquer momento, indivíduos demandando moeda e indivíduos poupando moeda. Assim, alguém retém moeda na forma de poupança, mas sua retenção, demandada por outro indivíduo que necessita de recursos momentaneamente, a mantém em circulação. Não fosse assim, a velocidade de circulação da moeda tenderia ao infinito. Essa explicação justificaria, ainda, o fato de que poupar seria qualitativamente diferente de entesourar, pois com a interveniência dos bancos, a poupança, diferentemente do entesouramento, retorna à circulação mais rapidamente. ${ }^{12} \mathrm{O}$ dinheiro poupado, que seria "dead capital", transforma-se, pela realocação realizada via empréstimos bancários, em "fruitful capital". É assim que, para ele, "Money is usually said to constitute a means of saving and of transferring capital (loans)" (Lectures, II, p. 24, itálicos originais).

Em Wicksell haverá consistência num sistema econômico em que ofertantes e demandantes de poupança possam operar num nível de remuneração da poupança que engendre o equilíbrio. O equilíbrio é o ponto em que os planos dos indivíduos (entre poupar ou demandar recursos que foram poupados) sejam consistentes, sendo, portanto, único e final. Esse equilíbrio se dá ao nível de taxa de juros denominado taxa natural de juros: "The rate of interest at which the demand for loan capital and the supply of savings exactly agree, and which more or less corresponds to the expected yield on the newly created capital,

${ }^{10}$ De forma ainda bastante imprecisa, dado a novidade da ciência que estava fundando, Smith argumentava no Wealth of Nations que, como resultado da dinâmica do processo produtivo, os excessos de moeda que sobravam nos balanços das firmas ("lucros") seriam guardados em bancos. Os bancos, portanto, constituíam-se num "agente-cofre" onde se guardavam excessos de moeda já existente. Mas ele admite o fato de que, em havendo confiança nos bancos, estes poderiam emitir notas promissórias próprias que ganhavam as mesmas funcionalidades da moeda em algumas transações. Isto mostra que, embora não haja uma teorização a respeito: a abordagem smithiana admite de forma tímida que os bancos podiam criar moeda.

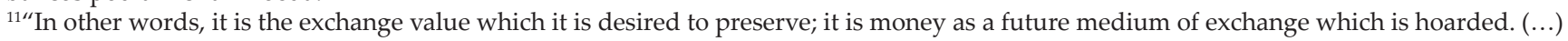
From the economic point of view of the individual the saving achieves its purpose, since the person saving will at a future date consume what he now forgoes and which somebody else will then forgo." (Lectures, II, p. 8)

$12^{\prime \prime}$ The money capital saved, usually through the medium of banks and savings banks, is loaned as quickly as possible and is thereby returned to circulation. From the individual's point of view, this means the transformation of dead capital into fruitful capital, with an interest-bearing claim guaranteed by the bank. Even if the money bears no interest there is still the advantage that the individual is spared the anxiety of guarding his hoard." (Lectures, II, p. 10). 
will then be the normal or natural real rate. It is essentially variable" (Lectures, II, p. 193, itálicos originais).

No seu Interest and Prices (Wicksell, 1898) ele se refere a ela como uma taxa neutra, em que preços e salários se mantém estáveis,

THERE is a certain rate of interest on loans which is neutral in respect to commodity prices, and tends neither to raise nor to lower them. This is necessarily the same as the rate of interest which would be determined by supply and demand if no use were made of money and all lending were effected in the form of real capital goods. It comes to much the same thing to describe it as the current value of the natural rate of interest on capital. (Wicksell, 1898, p. 102)

Wicksell acreditava que ambas as definições eram equivalentes. Em última análise, a taxa de juros substitui o conceito vago de parcimônia como razão fundante do hábito de poupar. No esquema wickselliano, a taxa de juros é uma medida da produtividade marginal real do capital, ou o "preço da espera". ${ }^{13}$ Mas deve-se perceber que, no esquema wickselliano, a poupança é que possui papel preponderante sobre o investimento, porque este último é determinado por ela. Na sua análise, a poupança é uma variável de escolha dos agentes econômicos sobre como alocar sua participação no produto total, consumindo-o no presente ou no futuro. Isso determina a possibilidade de que agentes com perspectivas de ganho econômico em algum negócio capitalista possam tomar empréstimos nos bancos a fim de investir. ${ }^{14}$ A poupança monetária, criando fundos emprestáveis por intermédio dos bancos, coloca a economia em um grau de funcionamento mais "capitalista" e mais direcionado para o futuro, o crescimento e a acumulação. ${ }^{15}$ A causalidade da acumulação de capital, em Wicksell, parte do poupador. O investidor só investe os recursos que o poupador quiser disponibilizar para empréstimo via bancos. O banco wickselliano é então, primordialmente, a instituição que aloca fundos emprestáveis entre diferentes agentes da economia.

\section{2 - O papel do crédito numa economia monetária}

O banco wickselliano aprende a dar um passo adiante na sua tarefa de alocar fundos emprestáveis. Complementarmente a esse papel distributivo, os bancos desenvolveram historicamente a função de concessão de crédito. Assim, na análise de Wicksell, o próximo passo é estudar as relações do crédito com a estabilidade do valor da moeda - novamente, dentro dos limites da TQM - tendo como objetivo demonstrar que o crédito não altera substancialmente as relações fundamentais dessa abordagem. ${ }^{16}$

A função de crédito é qualitativa: o crédito é uma alavanca que aumenta a velocidade da moeda sem aumentar os requerimentos de moeda (em "espécie") ${ }^{17}$ pois o crédito possibilita a emissão de substitutos da moeda como reserva de valor, os quais servem aos mesmos propósitos que o dinheiro em si. A origem do crédito se desenvolve historicamente com a emissão de cartas de crédito, com garantias e direitos de recebimento estabelecidos em algum tipo de relação contratual, mas é nos bancos e nos mercados de ações que o crédito encontra sua melhor organização e desenvolvimento, com as bolsas de valores atuando no crédito de longo prazo, enquanto aos bancos cabe o crédito de prazo mais curto (Lectures, II, p. 24). Os bancos aprenderam, ao longo do seu desenvolvimento como empresas, que podiam movimentar financeiramente os depósitos recebidos (cash holdings em seus cofres), ampliando a sua função para um papel mais ativo, de emissores de crédito. Essa é a tecnologia bancária fundamental, descoberta historicamente através da experiência de lidar com baixas probabilidades de retirada, que resultou em definir o papel do banco como instituição de crédito. Esse desenvolvimento da tecnologia bancária do crédito constitui um dos diferenciais da análise wickselliana dos bancos:

The discovery that money deposited on a guarantee to repay on demand could be partially loaned without endangering the liquidity of the institution in question constituted, however, an important advance in banking technique, which in its turn led to the discovery of the credit note. For just as simply as deposits of money were accepted against a certificate of deposit and were then lent out to others, whilst the certificate of deposit might continue to be used by the owner as a medium of payment and be transferred to others, so also such certificates of deposit might be issued against ample security to persons who had not deposited any money in the bank. (Lectures, II, p. 76).

Wicksell analisa os casos particulares de que dispõe para entender o fenômeno do crédito bancário em sua época, ${ }^{18}$ mas sua

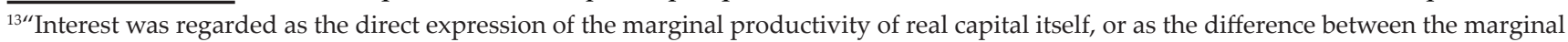
productivity of saved and current (present) labor and land; or, more correctly, as the marginal productivity of 'waiting' (...)." (Lectures, II, p. 5)

${ }_{14}$ "By saving in the modern sense a man entrusts his savings as they are accumulated to a bank, which lends them as quickly as possible to some enterprise which employs them productively in one way or another." (Lectures, II, p. 11-12)

${ }^{15}$ “Apart from some inevitable economic friction everything else will remain unchanged at the moment of saving, but production will have become more capitalistic, i.e. directed more towards the future, and consequently, as a rule, more fruitful." (Lectures, II, p. 12, itálicos nossos).

${ }^{16}$ “ My purpose is rather to attempt to describe the theory of money, still so greatly neglected by political economists, and the great principles underlying the variable complex of monetary phenomena. We are also concerned here with banking and the system of credit, but only in so far as they influence monetary phenomena, velocity of circulation, the demand for money, the level of prices, and so on." (Lectures, II, p. 79)

${ }_{17 "}$ "Clearly, there is a close connection between money and credit, in so far as credit is the best lever for increasing the velocity of circulation and thus diminishing monetary requirements." (Lectures, II, p. 24)

${ }^{18}$ Ao longo do texto são citados exemplos de bancos de Hamburgo, Amsterdam e da Inglaterra, o sistema escocês, as "clearing houses" do sistema americano, o sistema de poupança austríaco, enfim, um leque extenso de exemplos para os quais ele vai buscar compreender os elementos 
conclusão é mais generalizada: os bancos que ele avalia constituem o que ele denomina de bancos de tipo moderno, os quais aprenderam a lidar ativamente com suas carteiras de depósitos. Para essa classe de bancos vale que:

The most characteristic feature is that it accepts deposits both for repayment on demand (money at call, account, current, etc.) and on notice, whilst lending as large a part of these deposits as is consistent with safety, sometimes with, and sometimes without, the concurrent issue of their own banknotes. (Lectures, II, p. 80).

A operação ativa dos bancos é de curto prazo, mas a função principal que eles desempenham é a de alongamento do crédito, baseados na aplicação direta da Lei dos Grandes Números ao gerenciamento da concessão de crédito como forma de alavancar suas finanças e a de seus clientes:

[...] it may be said that one of the most important functions of the banks is precisely to prolong credit, i.e. to assemble the credit which in the nature of things can only be given for a short or uncertain period of time and then because of the Law of Large Numbers, (...) to convert them into more stable credit in the interests of borrowers and producers. (Lectures, II, p. 80)

Wicksell reconhece que não é condição necessária para a existência de um sistema de concessão de crédito que exista a figura do intermediário de crédito - o banco. Relações de crédito podem surgir entre os indivíduos de forma autônoma, inclusive com propósitos de prazo mais longo, em que relações contratuais baseadas na confiança mútua são mais importantes. Mas nas alocações de curto prazo, onde a coleta de informações sobre ofertantes e demandantes de crédito não é trivial, poderia resultar que os recursos ficassem imobilizados por tempo indeterminado. A existência de um sistema regulado de crédito possibilita a realocação mais célere de recursos. Esse é, precisamente, o espaço de atuação dos bancos: na concessão de créditos no curto prazo (Lectures, II, p. 81-82).

Concluindo o seu arrazoado, Wicksell chega ao entendimento do funcionamento do sistema de reservas fracionárias como o elemento que permite aos bancos operar alavancados. Por esse sistema, que - nas suas palavras - os bancos levaram "séculos para aprender", é possível administrar ativamente a concessão de crédito lastreado em frações dos recursos que, sob um sistema totalmente passivo, estariam depositados improdutivamente nos cofres dos bancos. De fato, de um lado, o sistema repousa sob a aplicação direta da Lei dos Grandes Números, que assegura baixíssimas probabilidades de retiradas simultâneas de todos os recursos depositados ao mesmo tempo (Lectures, II, p. 83). Por outro lado, o sistema resultou do aprendizado de que, na prática, a relação de vários clientes diferentes primeiramente entre si e com o mesmo banco, ou mesmo a relação de vários diferentes clientes com vários diferentes bancos, possibilita que pagamentos e recebimentos possam ser feitos apenas com registros contábeis a débito e crédito, dispensando moeda em favor de cheques e ordens de pagamento (Lectures, II, p. 84).

No limite, analisando o caso particular em que toda a economia dependesse de um único banco, ou na qual todas as transações monetárias estivessem circunscritas a um sistema integrado de bancos, onde todos os indivíduos depositassem suas poupanças e onde todos os pagamentos e recebimentos fossem realizados somente via esse grande banco único ou esse sistema coordenado, Wicksell propõe uma economia de crédito puro, onde não seria necessário sacar depósitos. Numa economia dessa natureza, seria hipoteticamente possível criar crédito infinito, em tal montante que a economia poderia vir a se descolar do setor real, gerando claramente um desequilíbrio do lado monetário em relação ao lado real. Alcançado esse ponto, a economia estaria numa trajetória de não-retorno, em que os desequilíbrios se tornariam cumulativos. Nesse sentido, o banco wickselliano estaria diante de duas possibilidades mutuamente conflitantes: ou o banco não altera em nada o sistema (nesse caso, perfeitamente inscrito num modelo de corn economy); ou o banco é capaz de gerar desequilíbrios extremos, "explodindo" a economia (a velocidade de circulação tenderia ao infinito, e uma pequena quantia de moeda seria suficiente para alavancar um volume gigantesco de produção e negócios). É justamente o fato de que os bancos não funcionam assim, que evita a espiral explosiva de crédito, pois,

To avoid misunderstanding it must be observed here that the above remarks only apply to a bank or a co-ordinated system of banks which has absorbed all the monetary transactions of the country. And even so it only applies to the internal turnover. If, on the other hand, the banks are more or less isolated from each other, as is actually the case, then each bank must be very careful not to extend its credit too far. (Lectures, II, p. 85-86) ${ }^{19}$

comuns e as tendências mais importantes.

${ }^{19}$ De certa forma, esse sistema constituiria o que Wicksell chamou de "Ideal Bank", o qual, embora de interesse teórico, enfrentaria certas dificuldades práticas de ser implantado, as quais ele enumera: "(1) the special requirements of small payments for wages, retail trade, etc.; (2) international payments; and (3) the circumstance, with which we have so far concerned ourselves very little, that the precious metals, in addition to their use for currency, are also the raw materials of certain industries." (Lectures, II, p. 87). Claro que as três circunstâncias limitadoras são historicamente datadas. 


\section{3 - Avaliação dos bancos na abordagem de Wicksell}

Wicksell construiu uma teoria que, nos limites da TQM, conseguiu achar uma explicação para a existência dos ban$\cos$, da poupança em forma monetária, dos mecanismos do crédito e do sistema de reservas fracionárias, elementos estes que estão na base de uma economia monetária. Uma contribuição importante pelo seu pioneirismo, como tentativa mais madura de construir uma teoria bancária coerente, com maior poder explicativo, e porque alguns elementos de sua análise permaneceram no arcabouço das abordagens ortodoxas: o papel dos bancos como intermediários de fundos emprestáveis entre agentes com diferentes posições passivas, o crédito como alavanca para o crescimento, e a racionalidade do sistema de reservas fracionárias. Ao falar sobre a coordenação de bancos, as transações utilizando cada vez mais lançamentos contábeis e menos moeda em espécie, clearing houses e o papel das bolsas de valores, Wicksell anteviu um sistema financeiro organizado, capaz de alavancar o crescimento - mas, obviamente, um sistema ainda não regulado em sentido estrito, com uma coordenação ainda incipiente e frágil. Não obstante, esses elementos de natureza histórica e institucional, de path dependence, de evolução dos bancos, constantes do esforço teórico wickselliano, foram ignorados em nome de maior rigor formal e generalidade das abordagens mainstream.

É importante frisar que Wicksell deixou em aberto para as gerações seguintes dois problemas que ele não conseguiu solucionar adequadamente: em primeiro lugar, a causalidade do par poupança-investimento. Wicksell é uma das fontes da causalidade da poupança para o investimento, o que, afinal, está em contradição com a tese de que os bancos são agentes ativos na economia monetária. Em segundo lugar, ele não solucionou a questão da não-neutralidade da moeda, tanto no curto como no longo prazo.

Em que pese a inovação de sua análise, já avançada para a época, as questões em aberto da teoria de Wicksell continuaram sendo tratadas de forma insatisfatória nas abordagens posteriores. Em particular, a causalidade da poupança para o investimento deixa o banco wickselliano numa posição final que é, de fato, passiva. Ele só pode conceder empréstimos ou crédito porque foi utilizado primeiramente como um cofre-forte, mesmo quando lança mão do crédito como alavanca monetária. Wicksell, nesse ponto, embora tenha teorizado com desenvoltura sobre a economia monetária, não lhe tirou dos limites estritos do domínio de uma corn-economy analisada sob a TQM. A teoria bancária que encontra raiz em Wicksell reflete os limites dessa perspectiva.

\section{Os bancos na abordagem de Keynes: o Treatise e as questões de não-neutralidade da moeda}

Keynes foi um seguidor fiel das ideias centrais da ortodoxia econômica até o início dos anos de 1930. A guinada no seu pensamento se dá após a frustração gerada em torno do seu Treatise on Money (1930), em que ele procurou explicar a TQM em termos dinâmicos, encontrando importantes fissuras dessa abordagem, sem, contudo, aprofundar-se nelas. Esse é um trabalho que virá somente depois, no contexto da elaboração da General Theory (Keynes, 1937 [1973]). ${ }^{20}$ Ainda assim, o Treatise se constitui na principal referência para sua abordagem sobre bancos. ${ }^{21}$

Em 1933 Keynes divulgou num artigo a intenção de buscar uma nova teoria monetária que rompesse com a neutralidade da moeda não apenas nos processos, mas também nos resultados. ${ }^{22}$ Nessa perspectiva revolucionária, a moeda afeta os motivos pelos quais os agentes orientam suas decisões. Keynes quer descrever a economia a partir do seu resultado final, e esse resultado deve corresponder biunivocamente ao mundo real. Uma teoria de moeda neutra é inadequada para explicar o que ele denomina de economia monetária de produção. A questão que o move nesse momento é como deve ser descrita teoricamente uma economia em que a moeda não seja neutra. Keynes quer encontrar um modelo descritivo de uma economia em que a moeda não seja neutra nem no curto nem no longo prazo.

Tendo a firma capitalista como a instituição chave de seu corpo analítico, Keynes advoga que, com a motivação de obter lucro (isto é, sair do processo produtivo com mais volume de dinheiro do que aquele com o qual entrou), as firmas efetivamente buscam riqueza em sua forma monetária. Fazendo uma rara concessão a Marx, em relação à ideia de acumulação via processo produtivo, ${ }^{23}$ Keynes defende que as firmas, sem sofrer ilusão monetária, buscam ativamente mais dinheiro ao final do ciclo

\footnotetext{
${ }^{20}$ No que segue, Treatise será utilizado para referir-se ao "A Treatise on Money" (Keynes, 1930 [2011]), seguido do volume (sem citação corresponde ao volume I) e páginas nessa edição, e GT (ou "Teoria Geral”) para a "General Theory of Employment, Interest and Money" (Keynes, 1937a [1973]).

${ }^{21} \mathrm{O}$ desejo de Keynes no Treatise era compreender as questões empíricas da economia, que se constituíam no objeto de sua investigação e acompanhavam-no desde a elaboração de Economic Consequences of the Peace (Keynes, 1919): o que eram e como se comportavam o consumo, a renda, a poupança e o investimento numa economia capitalista moderna. Da sua experiência profissional Keynes percebia que, empiricamente, a tese da não-neutralidade da moeda não possuía aderência à realidade. Mas no Treatise ele manteve-se fiel à tradição, embora incorrendo no preço de encontrar alguns enigmas que não conseguiu solucionar com o ferramental da TQM.

22 "In my opinion the main reason why the problem of crises is unsolved, or at any rate why this theory is so unsatisfactory, is to be found in the lack of what might be termed a monetary theory of production. (...) The theory which I desiderate would deal, in contradistinction to this [a real-exchange economy], with an economy in which money plays a part of its own and affects motives and decisions and is, in short, one of the operative factors in the situation, so that the course of events cannot be predicted, either in the long period or in the short, without a knowledge of the behavior of money between the first state and the last. And it is this which we ought to mean when we speak of a monetary economy." (Keynes, 1936b [1973], pg. 408-9]).

${ }^{23} \mathrm{~A}$ conhecida formulação marxiana de D-M-D': as empresas empregam dinheiro (D) para produzir mercadorias (M) com vistas a obter mais dinheiro depois da venda de sua produção $\left(\mathrm{D}^{\prime}\right.$, com $\left.\mathrm{D}^{\prime}>\mathrm{D}\right)$. Marx quer destacar que o processo produtivo capitalista começa e termina tendo o dinheiro como referência.
} 
de produção e venda do produto do que o montante com o qual iniciaram o processo. Mais ainda, elas o fazem por causa das propriedades intrínsecas da moeda: ela é desejada pelos agentes por ser um ativo financeiro, assim como o são títulos ou bens de capital, mas, diferentemente daqueles, sua conversibilidade é a mais alta entre todas as categorias de ativos existentes. ${ }^{24}$ Assim, firmas demandam moeda porque elas têm uma distância temporal entre o tempo da produção e o da obtenção de receita das mercadorias que produzem, necessitando de um ativo que possa honrar contratos a qualquer tempo, para "comandar" trabalho. O dinheiro constitui riqueza, e riqueza, do ponto de vista das firmas, é capacidade de comandar trabalho. ${ }^{25}$

\section{1 - Bancos no Treatise}

Uma das contribuições fundamentais do Treatise, que Keynes mesmo cita no prefácio da obra, é o seu tratamento dos sistemas monetários e bancários. Ele trata os bancos de forma explícita, como parte fundamental do mecanismo de funcionamento de uma economia moderna. Em primeiro lugar, os bancos emitem o que ele denomina de moeda bancária (bank-money): um reconhecimento de dívidas, expresso em moeda de conta (money-of-account, a unidade de medida de valor, e o money proper ou state money, o meio de liquidação de obrigações contratuais reconhecido pelo estado), que possui ampla aceitação como instrumento de transferência de dívidas. ${ }^{26}$ A moeda bancária pode representar em última instância um débito para com o próprio Estado, se este a reconhecer como instrumento de pagamento de dívidas contra ele. Nesse sentido, a moeda bancária torna-se moeda representativa (representative-money), com o Estado declarando aceitáveis quaisquer instrumentos denominados em moeda de curso legal que tenham sido emitidos como dívida junto a bancos. ${ }^{27}$

Assim, um dos papéis dos bancos é ser depositário de parte do volume total de moeda corrente (current-money), atuando num esquema semelhante a um sistema planetário, na metáfora utilizada por Keynes: "The typical modern Banking System consists of a Sun, namely the Central Bank, and Planets, which (...) it is convenient to call the Member Banks. The total stock of State-Money is held partly by the Public, partly by the Member Banks, and partly by the Central Bank" (Treatise, Vol. 1, p. 9). Os bancos possuem um papel ativo na condução das atividades relacionadas à administração dos volumes de moeda administrada (managed money), que é a forma representativa da moeda moderna: a moeda fiduciária - moeda cunhada, cartal, representativa, cujo valor é denominado pelo Estado (sem ter, necessariamente, valor fixado em nenhum tipo de padrão objetivo), ${ }^{28}$ a qual Keynes diferencia da moeda mercadoria (Treatise, p. 7), tão peculiar à análise quantitativista. É esta tarefa de cuidar da moeda administrada que faz emergir no sistema bancário a taxa bancária, como a taxa de juros que serve de referência fundamental de operações das firmas bancárias na manutenção de reservas de moeda.

Da análise das categorias de moeda e de suas inter-relações, Keynes parte para a explicação dos bancos com mais especificidade. A primeira definição de banco está ligada, então, a essa característica do banco como um transferidor de direitos de dívida denominados em moeda. Bancos emitem moeda quando criam dívidas contra si mesmos, denominadas em moeda, seja na forma de depósitos para resgate futuro por parte dos depositantes, seja na aquisição de ativos financeiros por meio da emissão de passivos, ou ainda pela concessão de empréstimos sem garantias, tendo como base o seu relacionamento com seus clientes. ${ }^{29} \mathrm{O}$ ponto importante é que

\footnotetext{
${ }^{24}$ Particularmente a prova dessa argumentação só é realizada com maior detalhe no Capítulo 17 da GT e na defesa da obra, num importante artigo publicado no QJE, em 1937 (Keynes, 1936a [1973]; 1937b).

${ }^{25}$ Nesse aspecto, emerge mais uma característica do modelo keynesiano: as economias capitalistas modernas são economias contratuais, em que contratos denominados em uma moeda de curso forçado constituem-se no mecanismo básico de coordenação do sistema (ver Davidson, 1978; 1994; Carvalho, 1992).

${ }^{26} \mathrm{Ou}$ seja, possui marketability, uma das características do conceito fundamental de liquidez (embora esse não seja ainda o conceito utilizado por Keynes no Treatise; ver Carvalho, 1992). "Bank-Money is simply an acknowledgement of a private debt, expressed in the money-of-account, which is used by passing from one hand to another, alternatively with Money-Proper, to settle a transaction. We thus have side by side State-Money or Money-Proper and Bank-Money or Acknowledgements-of-Debt" (Treatise, p. 6).

${ }^{27} \mathrm{De}$ fato, Keynes observa que a moeda bancária tem existência pretérita à moeda representativa, cujo desenvolvimento é posterior e devido justamente ao uso, pelo Estado, de "bank-money": "For the use of Bank-Money depends on nothing except the discovery that, in many cases, the transference of the debts themselves is just as serviceable for the settlement of transactions as is the transference of the money in terms of which they are expressed." (Treatise, p. 15)

${ }^{28} \mathrm{Ou}$, lembrando a metáfora da qual Keynes lança mão, do pagamento contratado em valor equivalente ao "peso do rei da Inglaterra" (ou seja, na ocasião do pagamento, vale o peso do regente à época): "It is for the State to declare, when the time comes, who the King of England is" (Treatise, p. 4). O Estado é o dono do "dicionário" que traduz o valor da moeda (money-of-account) a cada momento, e cabe ao Estado, somente, o poder discricionário de poder reescrever o dicionário de tempos em tempos (idem). O Estado faz emergir, portanto, essa era da moeda cartal: "And the Age of Chartalist or State Money was reached when the State claimed the right to declare what thing should answer as money to the current money-of-account - when it claimed the right not only to enforce the dictionary but also to write the dictionary. Today all civilized money is, beyond the possibility of dispute, chartalist." (Treatise, p. 5)

${ }^{29 " A}$ modern bank is an institution which is made possible by the establishment of habits of this kind" (Keynes está falando da aceitação de transferência de dívidas em substituição à moeda na qual elas estão denominadas; Treatise, p. 23). E explica, adiante: “Such a bank creates claims against itself for the delivery of money, i.e. what, hereafter, we shall call Deposits, in two ways. In the first place it creates them in favor of individual depositors against value received in the shape either of cash or of an order (i.e. a check) authorizing the transfer of a deposit in some bank (...)" (idem). Ou ainda: "It may itself purchase assets, i.e. add to its investments, and pay for them, in the first instance at least, by establishing a claim against itself. Or the bank may create a claim against itself in favor of a borrower, in return for his promise of subsequent reimbursement; i.e. it may make loans or advances" (Treatise, p. 23-24).
} 
In both cases the bank creates the deposit; for only the bank itself can authorize the creation of a deposit in its books entitling the customer to draw cash or to transfer his claim to the order of someone else; and there is no difference between the two except in the nature of the inducement offered to the bank to create the deposit. (Treatise, p. 24).

Percebe-se que, para Keynes, o papel do banco não é de maneira nenhuma um papel passivo (como nas teorias de fundos emprestáveis). Bancos agem ativamente de forma a obterem recursos junto a terceiros, criando depósitos e emitindo dívida. A "tecnologia" de gestão da firma bancária é que a transforma numa atividade com características especiais: os bancos devem atuar de forma que seus ativos e passivos se anulem mutuamente..$^{30}$ Os bancos podem criar ativamente depósitos a uma taxa apropriadamente ajustada à sua disponibilidade de recursos em caixa, ou seja, em termos gerenciais a atividade bancária consiste em administrar reservas ajustadas aos seus depósitos. ${ }^{31}$

Nesse ponto, Keynes rompe frontalmente com a perspectiva tradicional que vê na atividade dos bancos uma atuação passiva, limitada pela espera de que depositantes procurem o banco a fim de confiar-lhe suas poupanças. Essa é a perspectiva dominante, que vê no depositante a iniciativa da ação de criação de depósito junto aos bancos, e que é assim percebida, como ele exemplifica, pelos "practical bankers". Keynes chama a atenção para o fato de que são esses depósitos, chamados passivos (pois seriam aqueles em que os bancos esperariam pela decisão de poupar dos agentes) que são gerados pelos depósitos ativos, os quais são criados pelos próprios bancos:

Even if we look at the matter from the standpoint of one bank amongst many, it is apparent that the rate at which a bank passively creates deposits partly depends on the rate at which it is actively creating them. (...). For to the extent that the borrowing customers pay away their deposits to customers of other banks, these other banks find themselves strengthened by the growth of their passively-created deposits to the same extent that the first bank has been weakened; and in the same way our own bank finds itself strengthened whenever the other banks are actively creating deposits. (Treatise, p. 25-26)

É por essa circunstância que "so far from the actively-created deposits being the offspring of the passively-created deposits, it is the other way round" (Treatise, p. 26). ${ }^{32}$

Essa característica é fundamental para compreender porque uma economia monetária pode ser intrinsecamente instável. Para provar isso, Keynes argumenta em termos de um modelo hipotético de uma economia em que existe um sistema bancário fechado, onde todos os pagamentos são feitos por cheques, sem o uso direto de moeda ( cash) e onde os bancos não têm necessidade de manter saldo em reservas, quitando seus débitos interbancários por meio de transferências contábeis de ativos. Essa economia hipotética poderia, em última instância, não observar nenhum limite à criação de moeda bancária (desde que os movimentos de transferência de débitos sejam coordenados sequencialmente, ou "in step"). Esse sistema hipotético demonstra como uma economia monetária pode funcionar sem necessariamente ter que lançar mão de dinheiro existente para girar suas engrenagens. Desde que haja coordenação da ação dos bancos, os passivos e ativos se contrabalanceiam simultaneamente e nenhuma posição instável é mantida indefinidamente - o que corresponde, em média, ao padrão de comportamento do sistema bancário tomado como um todo. Nesse sentido Keynes chama novamente a atenção para o fato de que embora aparentemente a ação toda se desenvolva como produto da ação de depositantes, são os banqueiros que possibilitam essa coordenação, pois "Each Bank Chairman sitting in his parlour may regard himself as the passive instrument of outside forces over which he has no control; yet the 'outside forces' may be nothing but himself and his fellow-chairmen, and certainly not his depositors." (Treatise, p. 27).

Essa ação coordenada dos bancos é o que ele denomina de "sympathetic movement", a tendência a agir conforme a tendência do mercado, isto é, conforme uma convenção vigente num dado momento, como ele iria denominar esse tipo ação mais tarde, na Teoria Geral. ${ }^{33}$ Onde as condições para a existência de um sistema fechado sejam satisfeitas (como no caso de um país com moeda inconvertível), existe

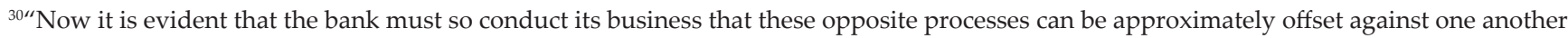
(...). The practical problem of the banker consists, therefore, in so managing his affairs that his daily accruing assets in the shape of cash and claims shall be as nearly as possible equal to his daily accruing liabilities in these forms." (Treatise, p. 24-5). É interessante observar que essa atividade, denominada em jargão bancário de ALM (Asset/Liability Management) ainda se constitui numa das principais atividades práticas dos bancos comerciais (Glantz, 2003; Gup e Kolari, 2005).

31 "It follows that the rate at which the bank can, with safety, actively create deposits by lending and investing has to be in a proper relation to the rate at which it is passively creating them against the receipt of liquid resources from its depositors." (Treatise, p. 25).

${ }^{32}$ Mais à frente, já em forma conclusiva, Keynes ainda se sente tentado a reforçar seu argumento, observando: "I have endeavoured to say enough to show that the familiar controversy as to how and by whom bank-deposits are 'created' is a somewhat unreal one. There can be no doubt that, in the most convenient use of language, all deposits are created by the bank holding them." (Treatise, p. 30, itálicos acrescentados).

${ }^{33}$ De fato, o sympathetic movement ganhou nova estrutura argumentativa e definição mais específica na GT, na forma das convenções do mercado, exemplificadas na conclusão da metáfora do concurso de beleza (Capítulo 12): “(...) we devote our intelligences to anticipating what average opinion expects the average opinion to be." (Keynes, 1936a [1973], p. 156). Por causa das convenções o mercado chega mesmo a cercear comportamentos não alinhados a ele: "Worldly wisdom teaches that is better for reputation to fail conventionally than to succeed unconventionally." (Idem, p. 158). Em certo sentido é semelhante à decisão do chairman de um banco - seguir a tendência geral, embora sem reconhecer que a tendência geral reflete a sua tendência individual. Vale observar que I. Fisher enxergava o mesmo componente convencional, no caso dos contágios de pessimismo que marcam períodos depressivos: "[...] pessimism, in a depression, become practically universal" (Fisher, 1932, p. 48). Esse pessimismo derivava, segundo ele, de um comportamento psicológico de massa, no qual uma opinião média se torna preponderante: "Everybody's opinion is largely guided by the opinion of everyone else; even the people with the coolest heads will at least 'fear the fears of other men' and contribute to the panic of which such fears are part." (Idem).
} 
uma grande tendência para a instabilidade sistêmica - a instabilidade é inerente a um sistema de pagamentos bancários sem moeda (cash):

A monetary system of this kind would possess an inherent instability; for any event which tended to influence the behaviour of the majority of the banks in the same direction whether backwards or forwards, would meet with no resistance and would be capable of setting up a violent movement of the whole system. (Treatise, p. 27) ${ }^{34}$

Keynes argumenta que o que evita o colapso desse sistema é uma combinação de gerenciamento de reservas por parte dos bancos (uma primeira manifestação de preferência pela liquidez por parte dos bancos, ainda que não nesses termos) com a ação de coordenação exercida pelo Banco Central. Basta que uma parte dos pagamentos tenha que ser feita em dinheiro para que surja a necessidade de manter reservas no caixa dos bancos - se uma parte dos pagamentos é em moeda, isso implica que uma proporção mais ou menos estável da moeda-bancária vai ser constituída de moeda de curso. A criação de mais moeda bancária pelos bancos drena dinheiro do sistema bancário como um todo (pois o volume de moeda bancária se afastaria dessa proporção estável em relação à moeda de curso). A ação preventiva dos banqueiros é, então, manter reservas em dinheiro, como forma de se proteger contra necessidades imprevistas de meio circulante. É a manifestação da preferência pela liquidez como forma de proteção dos bancos:

[...] a banker will always maintain some liquid resources in hand, partly in form of cash and partly in the form of deposits with some other bank or banks - which resources, called his "reserves", rise and fall with the volume of his deposits and sometimes by law or custom, are in a rigid ratio to them. (Treatise, p. 28)

A necessidade de manter uma parte das reservas em um "banco dos bancos" e de fechar diariamente as operações interbancárias (o que faz surgir a necessidade de uma clearing house), desenvolveu-se na direção da criação de bancos centrais nos sistemas bancários maduros, exercendo esses papéis de coordenação centralizada. ${ }^{35} \mathrm{O}$ Banco Central é, assim, um regulador do sistema, pois além de banco dos bancos, em algumas situações o nível de reservas passou a ser dado pelo BC. Mas o que Keynes pretende demonstrar é que a manutenção e o gerenciamento de reservas constitui-se na escolha crucial que os bancos tem de fazer a fim de perseguir suas metas de lucratividade e segurança: a primeira decisão do banco é o quanto de reservas é prudente manter - isso quando não forçado diretamente a manter um percentual estabelecido. Esse volume de reservas depende da escala das atividades do banco, que é medida pelo seu volume de depósitos e pelo tipo de atividades que ele financia. Mas essa decisão orientará, como consequência, o volume de recursos monetários que o banco disponibilizará à comunidade como um todo, pois

Having fixed on this proportion, the bank will then be as unwilling to see its reserves rise above it, since this generally means it is doing less profitable business than it might, as to see them fall below it. Consequently it will be actively creating deposits [...] according as its reserves, apart from day-to-day fluctuations, are showing a tendency to diminish or to increase. (Treatise, p. 28)

O que vale para o banco individual, vale para o sistema bancário como um todo. Assim, como resultado, tem-se que "it is the aggregate of the reserve-resources which determines the "pace' which is common to the banking system as a whole." (Idem). Cabe ao Banco Central o papel de coordenar essa atividade, pois

Assuming that the Central Bank is also the note-issuing authority, the aggregate reserve-resources of the member banks will be under the control of the Central Bank, provided the latter control aggregate of its note-issue and its deposits. In this case the Central Bank is the conductor of the orchestra and sets the tempo. (Treatise, p. 30)

Essa conjugação de comportamento prudencial por parte dos banqueiros e de coordenação por parte do Banco Central devolve estabilidade ao sistema. ${ }^{36}$

\section{2- Bancos, reservas bancárias e administração da liquidez}

Por lidar com moeda, os bancos explicitamente administram a liquidez dos seus balanços. A administração de liquidez pelos bancos,

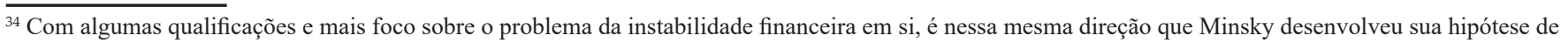
instabilidade financeira. Ver Minsky, 1982.

${ }^{35}$ Bagehot (1873 [2013]) descreve como esse processo se deu na City de Londres, culminando no estabelecimento formal do Banco da Inglaterra como banco dos bancos. Ver também Goodhart (1988).

${ }^{36}$ Não obstante, Keynes observa que, se aos bancos é dado certa capacidade de decidir discricionariamente a respeito de suas reservas, ainda assim o comportamento simpatético pode, mais uma vez, ocasionar o surgimento de crises, pois nesse caso "it will be difficult to restrain the inherent instability of the system" (idem). Vale observar que toda a obra minskyana está fortemente ancorada nessa percepção original de Keynes. 
em Keynes, engloba a manutenção de reservas em dinheiro (cash) proporcionais aos seus depósitos ou em patamares mínimos dados pelo Banco Central. A razão reservas/depósitos é, a um só tempo, um dos instrumentos pelos quais os bancos criam moeda e um canal de transmissão da expansão de volume de moeda por todos os bancos membros de um sistema bancário. Nos termos de Keynes, o volume de reservas de um banco, ao se alterar, reverbera por todo o sistema bancário (Treatise, II, p. 50). A expansão da razão reservas/depósitos de um banco em particular acabará por refletir-se em expansão nos demais bancos membros.

Esquematicamente, podemos mostrar essa proposição de Keynes da seguinte forma: dada um razão reservas/depósitos inicial, $\mathrm{R}_{0} / \mathrm{D}_{0}$, um aumento no volume de reservas causado por um acréscimo $\mathrm{R}_{1}$ tal que $\mathrm{R}_{1}>\mathrm{R}_{0}$, tornando $\frac{R_{1}}{D_{0}}>\frac{R_{0}}{D_{0}}$, induzirá um comportamento mais ativo do banco de forma a emprestar e investir um volume $\mathrm{D}_{1}$ tal que $\mathrm{D}_{1}>\mathrm{D}_{0}$. Qual o volume de $\mathrm{D}_{1}$ que recoloca a razão reservas/depósitos no nível desejado? Chamando $\frac{R_{1}}{D_{0}}>\frac{R_{0}}{D_{0}}$, onde $\bar{m}$ é um coeficiente fixado (rigorosamente, para o banco, é aquele exigido pelo banco central, $m_{B}$; pode-se considerar que o banco, por prudência, tenha a prática de manter um percentual adicional fixo sobre o nível exigido, $\bar{m}_{\mathrm{b}}$, de forma que, $\bar{m}=m_{B}+\bar{m}_{b}$ ) o nível de reservas volta ao patamar desejado fazendo-se $\frac{R_{1}}{D_{1}}=\bar{m}$, o que implica que $\mathrm{D}_{1}=\mathrm{R}_{1} / \bar{m}$. Note-se que $\frac{1}{\bar{m}}=\frac{D_{0}}{R_{0}}$, isto é, o multiplicador que os bancos levam em conta para expandir seus depósitos de forma a recompor suas reservas corresponde ao inverso da razão reservas/depósitos. Keynes postula que um banco em particular não fará a criação de depósitos de forma correspondente ao produto total do nível de reservas pelo inverso da razão ("the full multiple"), mas que o sistema bancário absorverá o choque inicial, nesse banco em particular, expandindo os depósitos em nível proporcional à expansão das reservas. O sistema como um todo acomoda o aumento de reservas ampliando os depósitos totais, e a oferta monetária se expande. O efeito final sobre preços, que Keynes avalia ainda sob a perspectiva quantitativista, não é direto como na TQM, porque depende da proporção em que ativos em circulação respondem a essa expansão das reservas (Treatise, II, p. 50-1). Em particular, não existe nenhuma relação determinística que torne fixado, ou estável, no curto prazo, o volume de dinheiro em circulação ao total de depósitos do tipo depósitos de renda (income-deposits). O aspecto de relativa importância é o fato de que a quantidade de moeda-bancária criada pelos bancos (por meio da emissão de depósitos) está em estrita sintonia com o nível de reservas exigidas, seja de forma sistêmica (por imposição da autoridade monetária, $m_{\mathrm{b}}$, por exemplo) ou por prudência dos próprios bancos, $\bar{m}_{\mathrm{b} .}{ }^{37}$

$\mathrm{O}$ argumento de Keynes esclarece dois pontos de discussão a respeito das reservas bancárias: o primeiro, que os bancos manteriam padrões variáveis de reservas acompanhando as flutuações do ambiente de negócios (afirmação que ele refuta), e segundo, a própria importância da manutenção de reservas em dinheiro para os bancos. Para Keynes, bancos buscam operar com o mínimo de reservas necessárias às suas operações normais, sem manter reservas inutilizadas acima desse mínimo, pois “they seldon or never maintain idle reserves in excess of what is their conventional or legal proportion for the time being" (Treatise, II, p. 53). O que Keynes destaca é que em uma economia moderna há sempre uma hierarquia de ativos, em termos de liquidez, de tal forma que existem sempre tipos de ativos que são muito líquidos, quase como a moeda, e que pagam algum juro, seguidos depois por outros tipos de ativos menos líquidos, mas que pagam juros maiores. De fundamental importância para os bancos é encontrar uma situação de equilíbrio, ou de compatibilização, entre ativos não monetários e passivos demandáveis a qualquer tempo, na forma de dinheiro, entre outras formas (por exemplo: lançamento a crédito) nas suas estruturas de balanço, de modo a maximizar a segurança que essa compatibilização possa trazer: "The problem before a bank is not how much to lend (...) but what proportion of its loans can be safely made in the relatively less liquid forms", afirma ele (Treatise, II, p. 53-4). Os bancos escolhem manter ativos que combinem liquidez com possibilidade de ganhos adicionais (na forma de juros ou valorização em mercados secundários), o que implica em que parte substancial das reservas pode não necessariamente estar constituída na forma de dinheiro. ${ }^{37}$

Além disso, as características de uma economia monetária são tais que o uso de dinheiro é cada vez mais restrito a poucas operações financeiras ou comerciais, sendo que o maior volume de operações podem ser realizadas somente por meio de registros a débito e crédito. O crescimento das operações quitadas por meio de lançamentos bancários e pagamentos com cheques e ordens de pagamento reduz significativamente o volume necessário de dinheiro para as operações diárias dos bancos. Por essa razão, não é lucrativo, do ponto de vista da operação bancária, manter reservas estéreis em dinheiro. Reservas em dinheiro são mantidas nos níveis absolutamente mínimos necessários, principalmente quando os bancos dispõem de outros ativos com liquidez elevada e que possibilitem algum ganho adicional, na forma de juros, por exemplo. A conclusão a que Keynes chega é que os bancos necessitam mais de liquidez do que de dinheiro no equilíbrio de seus balanços. A decisão crucial se dá em torno de liquidez e, particularmente, em que proporção alocar as opções de investimento que os bancos tiverem à sua disposição. ${ }^{38}$

Keynes lista em três as categorias que esses investimentos podem tomar, e compara as características predominantes dessas

\footnotetext{
${ }^{37}$ Lembrando, de passagem, que títulos (como títulos do banco central, "Bank Bills") possuem tais características, ele chama a atenção para esse aspecto prático do gerenciamento de reservas: "It must be the case that interest-yielding assets are available, the liquidity of which is beyond question. (...). The Bank Bill, therefore, is as good as gold - and better, because it earns interest. There is no reason, therefore, why a bank should sacrifice the interest thus obtainable (directly, or indirectly by call loans to the market) by holding cash in excess of what is required by the written, or the unwritten, law." (Treatise, II, p. 54-5).

${ }^{38 " \prime}(. .$.$) what bankers are ordinarily deciding is not how much they will lend in the aggregate - this is mainly settled for them by the state of$ their reserves - but in what forms they will lend - in what proportion they will divide their resources between the different kinds of investment which are open to them" (Treatise, II, p. 67). As implicações para a regulação prudencial de bancos ficam óbvias a partir dessa perspectiva. Cabe ao regulador estabelecer em que ativos os bancos podem investir, e nisso ele afeta a liquidez relativa desses ativos.
} 
três categorias, sob a ótica dos bancos, em termos de sua lucratividade e de sua liquidez:

Broadly there are three categories to choose from - (i.) Bills of Exchange and Call Loans to the Money market, (ii.) Investments, (iii.) Advances to customers. As a rule, advances to customers are more profitable than investments, and investments are more profitable than bills and call loans; but this order is not invariable. On the other hand, bills and call loans are more "liquid" than investments, i.e. more certainly realizable at short notice without loss, and investments are more "liquid" than advances. (Treatise, II, p. 67).

Keynes, portanto, discute pioneiramente a preocupação de bancos não apenas em manter reservas - o que fazem pelo mínimo, segundo ele - mas principalmente em examinar as características de liquidez e retorno dos ativos não monetários. Keynes adianta, portanto, um tratamento da preferência pela liquidez dos bancos, em especial quando os bancos lidam com a formação de reservas. Essa preferência pela liquidez dos bancos se revela principalmente na composição dos ativos monetários entre os 3 grupos que ele propõe (empréstimos, investimentos e adiantamentos a consumidores). A avaliação de quais ativos são mais desejáveis a cada momento depende das circunstâncias conjunturais, conforme a fase do ciclo em que a economia estiver. Nos seus termos:

Accordingly bankers are faced with a never-ceasing problem of weighting one thing against another; the proportions in which their resources are divided between these three categories suffer wide fluctuations, (...). When, for example, they feel that a speculative movement or a trade boom may be reaching a dangerous phase, they scrutinize more critically the security behind their less liquid assets and try to move, so far as they can, into a more liquid position. When, for the other hand, demands increase for advances from their trade customers of a kind which the banks deem to be legitimate and desirable, they do their best to meet these demands by reducing their investments and, perhaps, their bills; whilst, if the demand for advances is falling off, they employ the resources thus released by again increasing their investments. (Treatise, II, p. 67)

Keynes procura demonstrar sua teoria com um breve exercício empírico de análise dos sistemas bancários ingleses e norte-americanos, com foco, primeiramente, na forma como o nível mínimo de reservas é formalmente estabelecido em cada um dos dois sistemas. Ele manifesta preferência pelo sistema norte-americano, em que o nível de reservas é estabelecido por força de lei, de forma explícita e melhor definida, ao passo que o sistema inglês sofre, segundo ele, de indefinição e de uma convenção não muito bem estabelecida entre os próprios bancos. ${ }^{39}$

Em segundo lugar, ele busca uma outra rationale para a necessidade de que uma autoridade monetária, como o BC, exija a observância de manutenção de níveis adequados de reservas por parte dos bancos. Dois aspectos se destacam: primeiro, fazer com que os bancos contribuam diretamente com os gastos que o BC incorre na própria manutenção da moeda ("currency", Treatise, II, p. 74); segundo, conferir-lhe poder de fogo, por meio da sua disponibilidade, a custo negligível dos depósitos compulsórios realizados pelos bancos como parte da sua constituição de reservas, de garantir as operações de open-market que, afinal, existem a benefício do próprio sistema bancário e da estabilidade da economia como um todo.

\section{4 - O papel dos bancos em Keynes}

A construção teórica de Keynes em torno da moeda o leva a uma profunda reformulação também sobre o que é a atividade bancária. A Keynes não passa despercebido que o papel dos bancos é muito mais complexo do que simplesmente o papel de intermediar a transferência de fundos emprestáveis entre agentes superavitários e agentes deficitários. Percebe-se que o banco, na análise keynesiana, é um provedor de liquidez para os agentes. Na perspectiva keynesiana, ao poupar, os indivíduos demandam ativos para acumular riqueza, incluindo a moeda e os ativos financeiros nela denominados. A liquidez desses ativos tem peso fundamental nessa escolha.

Nas teorias anteriores a Keynes, só muito tangencialmente se explorou a capacidade dos bancos de criar esse tipo de ativos. O limite, como visto em Wicksell, é admitir que os bancos podem criar crédito, mas que o crédito deve ter uma natureza tal que seja ancorado em uma quantidade de moeda poupada. O crédito wickselliano ainda é uma variante de fundos emprestáveis. Mas Keynes, ao realizar o escrutínio detalhado da figura do depósito bancário, ao classificar analiticamente os tipos de depósitos e entender que parte deles são voltados para as operações correntes e somente parte deles destina-se à acumulação

\footnotetext{
${ }^{39}$ Ele argumenta, em relação ao caso inglês: "In Great Britain the reserve-ration to be maintained by the banks has never been fixed by law. During the earlier period of English Joint-Stock Banking it was left to the banks themselves to keep such amount as was dictated to them by considerations of prudence and of convenience" (Treatise, II, p. 68-9). Diferentemente, "In the United States the position is (...) rather different. The ratio, varying somewhat for differing types of banks, is laid down by law" (Idem, p. 70). Para Keynes, o sistema de definição legal é mais claro e mais eficiente, donde resulta sua preferência (Idem, p. 74).
} 
de riqueza, conseguiu lançar luz sobre o aspecto pouco intuitivo das atividades bancárias. Bancos não são meros intermediários; na verdade, eles criam ativos financeiros e injetam liquidez na economia. Essas são as funções que ele reconhece como intrínsecas às atividades bancárias:

[...] the modern banker performs two distinct sets of services. He supplies a substitute for State Money by acting as a clearing-house and transferring current payments backwards and forwards between his different customers by means of book-entries on the credit and debit sides. But he is also acting as middleman in respect of a particular type of lending, receiving deposits from the public which he employs in purchasing securities, or in making loans to industry and trade mainly to meet demands for working capital. (Treatise, II, p. 213)

Essa dupla função dos bancos foi ignorada nas TFE, e nas em outras abordagens teóricas em geral. ${ }^{40}$ Parte significativa dessa limitação teórica é devida ao fato de se trabalhar ainda num modelo de corn economy, em que a moeda não é mais que uma commodity tomada como numerário. Quando a moeda representativa assume a preponderância nas atividades econômicas a insuficiência teórica permanece, por insistir na tentativa de explicar o funcionamento do mundo a partir do modelo antigo de economia de trocas simples (que ademais já se mostra, nesse ponto, seriamente inadequado como modelo descritivo de uma economia monetária). ${ }^{41}$ A moeda representativa significa um novo estágio de aprimoramento nas atividades dos bancos, e um desafio. Como Keynes observa:

The next stage arrived when those who issued Representative Money (in the shape of Bank Money) combined with this the function of acting as intermediaries for loan-capital, and, furthermore, pooled the resources obtained in this capacity with those which they obtained as purveyors of Representative Money, and then proceeded to lend out as a single fund the joint proceeds of these two distinct operations. (Treatise, II, p. 214)

É assim, então, que "The dilemma of modern banking is satisfactorily to combine these two functions" (Treatise, II, p. 215). É também assim que, mesmo quando a análise se volta para o crédito, não é o montante de fundos emprestáveis que podem ser realocados intertemporalmente que limitam o volume de crédito que pode ser concedido pelos bancos, mas sim o nível de atividades que o banco está financiando e o nível de reservas que mantém. ${ }^{42}$ Quando um Banco Central regula de forma apropriada o nível de reservas dos bancos o resultado é que tampouco o crédito pode degringolar para uma sucessão de desequilíbrios crescentes com tendência cumulativa, como em Wicksell. Portanto, para Keynes, o crédito é "[...] the pavement along which the production travels; and the bankers, if they knew their duty, would provide the transport facilities to just the extent that is required in order that the productive powers of the community can be employed to their full capacity. (Treatise, II, p. 220).

$\mathrm{O}$ crédito então tem uma ligação direta com a liquidez das atividades produtivas correntes. Se há um limitador para o crédito, é que ele se situe na vizinhança de um equilíbrio entre o valor do novo investimento e a taxa de poupança corrente do público. ${ }^{43}$ Portanto:

[...] bankers are only entitled to create credit, without laying themselves open to the charge of inflationary tendencies, if the net effect of such credit creation on the value of new investment is not to raise the value of such investment above the amount of the current savings of the public; and, similarly, they will lay themselves open to the charge of deflationary action unless they create enough credit to prevent the value of new investment from falling below the amount of current savings. (Treatise, Vol. II, p. 220, itálicos adicionados)

\footnotetext{
${ }^{40}$ Keynes observa isso explicitamente, ao dizer que "This duality of function is the clue to many difficulties in the modern Theory of Money and Credit and the source of some serious confusions of thought."(Treatise, II, p. 214)

${ }^{41} \mathrm{O}$ que mais tarde Keynes viria a descrever, na Teoria Geral, como a tentativa da teoria "clássica" de insistir em ser euclidiana num mundo não euclidiano.

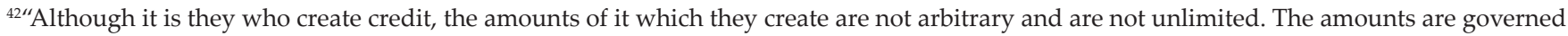
by the requirements of trade on the one hand, but also by the state of their reserves on the other." (Treatise, II, p. 219).

${ }^{43}$ Uma tentativa teórica alternativa de explicar o crédito é encontrada em von Mises (1953). Para von Mises: "The activity of the banks as negotiators of credit is characterized by the lending of other people's, i.e., of borrowed, money. Banks borrow money in order to lend it; the difference between the rate of interest that is paid to them and the rate that they pay, less their working expenses, constitutes their profit on this kind of transaction. Banking is negotiation between granters of credit and grantees of credit" de tal forma que 'Only those who lend the money of others are bankers.' (von Mises, 1953, p. 262, itálicos nossos). Sua argumentação não abandona a visão de que a poupança é uma parte do produto cujo consumo é transferido intertemporalmente. Não apresenta, portanto, nada de substancialmente novo em relação à análise wickselliana. Além disso, como lembra Tobin (1963), quando existem restrições de natureza legal sobre os bancos para pagarem juros sobre depósitos à vista, um argumento do tipo que é construído por von Mises perde sustentação. O perspectiva de Keynes, no entanto, não é abalada por limitações dessa natureza.
} 
O real critério de estabilidade, portanto, é o equilíbrio entre poupança e investimento, e os bancos determinam quanto eles emprestarão tomando como referência o quantitativo de suas reservas (Treatise, II, p. 222).

\section{Conclusão}

As modernas teorias de bancos são fundamentalmente ancoradas em duas escolas de pensamento principais. A teoria dominante, de coloração neoclássica, tem sua matriz conceitual num modelo econômico do tipo corn economy, e encontra em Wicksell a referência fundamental de uma teoria bancária baseada em fundos emprestáveis. O banco wickselliano é o pai do banco neoclássico, que, a bem da verdade, não tem uma papel bem definido a desempenhar numa economia teoricamente em equilíbrio com informação perfeita. A função do banco, numa economia dessa natureza, seria nula. Por isso as teorias derivadas dessa escola tem que lançar mão de hipóteses adicionais, como as de existência de informação assimétrica entre os agentes, de tal forma que a existência do banco se justifique como um mediador entre agentes superavitários e deficitários em termos de recursos para consumir intertemporalmente. Em última análise, o banco das teorias ortodoxas é o banco de Wicksell refinado para caber em modelos matemáticos mais precisamente definidos, mas ainda é o banco wickselliano.

Coube a Keynes fazer o contraponto teórico dessa abordagem, por meio da sua análise mais sistemática, detalhada e estruturada sobre os depósitos bancários e a função dos bancos numa economia monetária moderna. O banco keynesiano tem correspondente direto no mundo real - pode ser o banco de investimento ou o banco comercial, pode ser o shadow bank moderno, pode agrupar todo o sistema financeiro, porque, em Keynes, o banco é um provedor de liquidez para o sistema econômico. O banco de Wicksell e da tradição teórica de matiz ortodoxa é operacionalmente passivo e dependente da vontade de poupar dos poupadores superavitários. Sob certas circunstâncias, poderia criar desequilíbrios cumulativos que se manifestariam em elevação geral de preços, mas sem interferir com o equilíbrio descrito pela equação fundamental que rege o lado monetário da economia.

Em contraste a isso, o banco de Keynes é ativo e intrinsecamente ligado ao nível de atividade econômica - ao nível de investimento, portanto. Não se limita a alocar fundos emprestáveis: ele mesmo gera recursos com os quais irriga a economia de liquidez. Mas não desemboca no caos pura e simplesmente, porque é limitado por fatores objetivos: um regulador externo (um banco central), níveis de reservas mantidos como margens de segurança (além dos fatores de ordem institucional, como normas e obrigações legais às quais se submete em cada país), e sua ligação com o sistema empresarial, cujos investimentos financia.

\section{REFERÊNCIAS}

Bagehot, W. (1873 [2013]). Lombard Street: a description of the money market. New York: Create Spacing Publishing.

Baltenspeger, E. (1980). Alternative approaches to the theory of the banking firm. Journal of Monetary Economics, 1980.

Carvalho, F. J. C. (1992). Mr. Keynes and the Post-Keynesians: principles of macroeconomics for a monetary production economy. Aldershot (UK): Edgar Elgar Publishing.

Davidson, P. (1978). Money and the real world. $2^{\text {nd }}$ ed. London: MacMillan.

Davidson, P. (1994). Post Keynesian macroeconomic theory: a foundation for successful economic policies for the twenty-first century. Cambridge: Edward Elgar.

Diamond, D. W.; Dybvig, P. H. (1983). Bank runs, deposit insurance and liquidity. Journal of Political Economy, 91 (3): 401-409. Reprinted in: Federal Reserve Bank of Minneapolis Quarterly Review, Vol. 24, n. 1 (Winter, 2000$)$, pp. 14-23.

Fama, E. F. (1990). Banking in the theory of finance. Journal of Monetary Economics, 6 (1980), pp. 39-57

Fisher, I. (1932). Booms \& Depressions: some first principles. New York: Adelphi Company.

Freixas, X.; Rochet, J. C. (2008). Microeconomics of banking. $2^{\text {nd }}$ ed. Cambridge (Massachussets), The MIT Press.

Glantz, M. (2003). Managing bank risk. Academic Press/Elsevier, 2003. 
Goodhart, C. A. E. (1988). The evolution of central banks. Cambridge (MA): The MIT Press.

Gup, B. E.; Kolari, J. W. (2004). Comercial banking: the management of risk. $3^{\text {rd }}$ ed. Hoboken (NJ): John Wiley\& Sons.

Keynes, J. M. (1919 [2012]). The economic consequences of the peace. New York: Start Publishing LLC.

Keynes, J. M. (1930 [2011]). A treatise on Money: Vol. I - The pure theory of money; Vol. II - The applied theory of money. New York: Harcourt Brace and Company. (Two Volumes Complete in One).

Keynes, J. M. (1936a [1973]). The General Theory of Employment, Interest and Money. London: Macmillan for The Royal Economic Society (The Collected Writings of John Maynard Keynes, Edited by Donald Moggridge, Volume VII).

Keynes, J. M. (1936b [1973]). The General Theory and after: Part I - Preparation. London: Macmillan for The Royal Economic Society (The Collected Writings of John Maynard Keynes, Edited by Donald Moggridge, Volume XIII).

Keynes, J. M. (1937). The general theory of employment. The Quarterly Journal of Economics, Vol 51, n. 2, Feb. 1937, pp. 20923.

Minsky, H. P. (1982). Can "it" happen again? Essays on instability and finance. Armonk/New York: M.E. Sharpe.

Tobin, J. (1963). Comercial banks as creators of "money". Reprinted from Banking and Monetary Studies, ed. by Deane Carson, for the Comptroller of the Currency, U.S. Treasury (Homewood, Ill. Richard. D. Irwin, 1963), pp. 408-419.

Von Mises, L. (1953). The theory of money and credit. New Haven: Yale University Press.

Wicksell, K. (1898[1962]). Interest and prices: a study of the causes regulating the value of money. London: The Royal Economic Society, 1962.

Wicksell, K. (1934). Lectures on political economy - Vol. I: general theory. London: George Routledge \& Sons, Ltd., 1934.

Wicksell, K. (1935). Lectures on political economy - Vol. II: money. London: George Routledge \& Sons, Ltd., 1935. 